\title{
FSM GIANT SWAMP TARO SALINITY TOLERANCE EVALUATION
}

\author{
Lolita N. Ragus* ${ }^{1}$ and Werfina Sonis ${ }^{2}$ \\ *1,2 COM-FSM Chuuk Campus/Cooperative Research and Extension Weno, Chuuk FM 96942
}

\begin{abstract}
Giant swamp taro (Cyrtosperma chamissonis or C. merkusii Schott) is an important crop at atolls and mountainous islands in Micronesia. However, some dwellers abandon their taro patches damaged by recurrent wave surges and salt-water intrusion. We addressed this issue about threatened food security and impacts of climate change through a research endeavor funded under Tropical and Subtropical Agricultural Research Grant/United States Department of Agriculture. We focused on collection and evaluation of various cultivars of Cyrtosperma seedlings grown under fresh saltwater swamp for two years. We collected forty three cultivars from Chuuk and Pohnpei states of the Federated States of Micronesia. After morphological characterization of their petioles, leaves and corms, we identified 15 different groups. We determined percentage survival, mean sucker number, monthly mean corm size and leaf damages of these groups. Furthermore, two popular cultivars underwent time-series soaking in the ocean water with mean salt water concentration of 56,228 parts per million or ppm (5.6\%). Determining root losses, $\mathrm{P}$ and $\mathrm{K}$ of this taro seemed a promising practical evaluation method for salt tolerance. Both cultivars lost $50 \%$ of their roots at 28 -hour soaking, started increasing phosphorus $(\mathrm{P})$ removal from their tissues at 30 hours of soaking and absorbed potassium (K) from the soak water starting at two hours and onward. Afterwards, all groups soaked in ocean water with an average of 49, $928 \mathrm{ppm}(5.0 \%)$ for seven hours showed different magnitudes of losses in root number, cuts in intact roots and biomass.
\end{abstract}

Keywords: giant swamp taro, atolls, food security, salt tolerance, time-series soaking, ppm, biomass losses

\section{INTRODUCTION}

Giant swamp taro (Cyrtosperma chamissonis or C. merkusii Schott) is an important crop at atolls and mountainous islands in Micronesia. It is referred to as the "potato of the Pacific". It offers a continuity of food to people in low lying atolls throughout the years. However, the Federated States of Micronesia situated at $6^{0} 55^{\prime}$ North longitude and $158^{\circ} 11^{\prime}$ East latitude with four states (Chuuk, Kosrae, Pohnpei and Yap) is directly vulnerable to sea level rise that causes salinization and coastal erosion. According to

Brown (2014), global average sea level rise is about 3.2 millimeters $(\mathrm{mm})$ per year but tropical western Pacific had $12 \mathrm{~mm}$ per year sea level rise between 1993 and 2009.
Quick fix such as building seawalls to keep water out from the taro patches was not effective. In fact, some dwellers abandon their taro patches damaged by recurrent wave surges and salt-water intrusion. Such condition threatens food security in those affected areas. Hezel (2011) noted that normally two years of rainfall are required to flush out saline contamination in taro patches and another three years for taro growth from planting to harvesting..

Thus, the College of Micronesia-Federated of Micronesia conducted a collaborative research funded for two years in September 2011 to August 2013 with the American Samoa Community College (ASCC) and the United States Department of Agriculture

Corresponding Author: *lragus748@yahoo.com 
(USDA)/ Agricultural Research Service (ARS), United States Pacific Basin Agricultural Research Center (US PBARC) to improve taro productivity in the Pacific. The COM-FSM worked on giant swamp taro salt tolerance evaluation under this funding for two years and continued the study up to early 2014 to find out which cultivars could withstand effects of sea level rise. Other collaborators focused on other taro production issues.

This research worked on the premise that salt tolerance is an inherent ability of plants to withstand the effects of high salt concentration in the root zone or in the leaves without significant adverse effects (Torabi, 2014).

\section{MATERIALS AND METHODS}

\section{Collection}

Thirteen cultivars from Pohnpei $\left(6^{0}\right.$ 51'North longitude and $158^{\circ} 13^{\prime}$, East latitude ) and 30 cultivars from Chuuk $7^{0} 25^{\prime}$ North longitude and $151^{0}$ $47^{\prime}$ East latitude) were collected. Yap had burrowing nematode problems and Kosrae was close to Pohnpei so no collection was performed there. Ten corms for each cultivar were obtained from producers.

\section{Mild Salinity Evaluation}

Ten corms of each cultivar spaced at 1 meter (m) by 1 $\mathrm{m}$ were planted in non-replicated rows. Ten plants represented one cultivar. For more than two years, the growth and performance of the young seedlings were monitored monthly at a swamp with an average salinity of $1,300 \mathrm{ppm}(0.13 \%)$.

The growth parameters measured were plant height, number of stalks and leaves, monthly increment of corm diameter, leaf damages, leaf width and length, and seedling survival and number of suckers in each plant.

Monthly increment of corm diameter was determined from three plant samples uprooted after two years. The middle portion of the corm was measured. Average corm diameter among sample plants was divided by 24 months to obtain the monthly corm increment.
The seedling survival rate was based on the 10 seedlings in each cultivar collected and maintained at the swamp. Surviving original plants were counted and divided by 10 plants and values multiplied by 100 to determine the percentage survival rates.

The number of suckers was counted using the first suckers that were produced by the surviving original plants.

Plant height, number of petioles and leaves were direct measurements.

\section{Morphological Characterization}

After two years, the 43 cultivars of giant swamp taro were compared for their similarities and differences in color of leaves, petioles and corm flesh and presence of some structures like spines in the petioles and cataphylls (leaf-like) underneath the leaves.

\section{Sea Level Rise Evaluation}

In addition to evaluation in swamp for mild salinity, mimicry of the effects of sea level rise was conducted in two stages through soaking in pure sea water.

The first stage was soaking at 5.6\% salinity the two popular cultivars Fanan and Simiten for the timeseries soaking experiment ( 0 to 52 hours at 2 -hour intervals) to determine the shortest possible time for significant cultivars' responses to soaking in high salinity levels of water. Three plants in each cultivar were used for this experiment. Nutrients available in the soak water before and after soaking using LaMotte Fertility Kit were determined. The plant biomass (entire plants), root number and length and corm were measured before and after soaking.

From the results of the first experiment, 7- hour soaking was selected for evaluating all cultivars under high water salinity level averaging 53,000 ppm $(5.3 \%)$. Soak nutrients and plant parts affected before and after soaking were determined.

\section{Statistical Analysis}

Excel Analysis ToolPak kit was used for the Analysis of Variance (ANOVA) of growth parameters. LSD 
was employed for comparison of means of plant parts and soak nutrients before and after soaking.

\section{RESULTS AND DISCUSSION}

\section{Cultivar Characterization}

Fifteen cultivar groups were identified from 43 local giant swamp taro cultivars collected from Chuuk and Pohnpei states (Table 1). A manual with detailed description of the color of stalks, leaves and corm flesh and presence of special structures like was prepared and distributed to local communities in Chuuk and other states of the FSM (Ragus and Sonis, 2015).

Table 1. Grouping and morphological traits of 43 local cultivars.

\begin{tabular}{|c|c|c|}
\hline Groups & Local cultivars & Morphological traits \\
\hline 1 & Peremiong (1) & Green stalks, light green leaves and orange corm flesh \\
\hline 2 & Pwonon(1) & $\begin{array}{l}\text { Light green stalks with thick spines, green leaves and } \\
\text { yellow corm flesh }\end{array}$ \\
\hline 3 & $\begin{array}{l}\text { Fanan, Lirow, Mortlock,Ngangie, Powell, } \\
\text { Weito (6) }\end{array}$ & $\begin{array}{l}\text { Yellow green stalks with red, purple and black spots, } \\
\text { yellow green leaves and dark yellow corms }\end{array}$ \\
\hline 4 & Harry 1, Pwetepwet (2) & $\begin{array}{l}\text { Stalks with shot spines, yellow at upper and lower and } \\
\text { green with brown spots in the middle portion, light } \\
\text { green leaves and dark yellow corm flesh }\end{array}$ \\
\hline 5 & Simiten, Unknown (2) & $\begin{array}{l}\text { Pink and yellow stalk base, upper base green and light } \\
\text { orange, light green purplish streaks for upper stalk, } \\
\text { green leaves and yellow corm flesh }\end{array}$ \\
\hline 6 & Fanan, Simiten (2) & $\begin{array}{l}\text { Light yellow stalks with black, green and black spots, } \\
\text { green leaves and dark yellow corm flesh }\end{array}$ \\
\hline 7 & Pachon, Sari(2) & $\begin{array}{l}\text { Stalks, green at upper, dark green at lower and yellow } \\
\text { and blue at base, green leaves and yellow corm flesh }\end{array}$ \\
\hline 8 & Fanan, Kemesek and Parotorot (3) & $\begin{array}{l}\text { Stalks, reddish brown inside and red outside, light green } \\
\text { leaves and dark orange corm flesh }\end{array}$ \\
\hline 9 & Leongmwar, Simiten, Weito, Simiten (4) & $\begin{array}{l}\text { Stalks, light brown inside, pink outside with spines and } \\
\text { yellow base with black dots, light green leaves and } \\
\text { yellow corm flesh }\end{array}$ \\
\hline 10 & $\begin{array}{l}\text { Alengaleng (Weno and Pohnpei), } \\
\text { Manikoko, Salengwalek (4) }\end{array}$ & $\begin{array}{l}\text { Stalks, green at upper and black wavy bands above base } \\
\text { and black base, green leaves with leaf-like structures } \\
\text { underneath and dark yellow corms }\end{array}$ \\
\hline 11 & Pwetata, Tigerall (2) & $\begin{array}{l}\text { Stalks, green with black and yellow bands, black base, } \\
\text { light green leaves and orange corm flesh }\end{array}$ \\
\hline 12 & Pulapwech , 2 unknown names (3) & $\begin{array}{l}\text { Green stalk streaked with red and with spines, green } \\
\text { leaves, yellow corm flesh }\end{array}$ \\
\hline 13 & $\begin{array}{l}\text { Harry 2, Lepachon, Manikoko, } \\
\text { Pulamwariw (4) }\end{array}$ & $\begin{array}{l}\text { Spiny stalks, green upper, light green lower, black base, } \\
\text { light green leaves and dark yellow corm flesh }\end{array}$ \\
\hline 14 & $\begin{array}{l}\text { Anechimo, Simiten (Weno and Pohnpei), } \\
\text { Unknown (4) }\end{array}$ & $\begin{array}{l}\text { Stalks, black at lower and green at upper, light green } \\
\text { leaves and yellow corm flesh }\end{array}$ \\
\hline 15 & Fonon, 2 unknown names Unknown (3) & $\begin{array}{l}\text { Stalks, yellow with red streaks for upper and purple } \\
\text { dots at middle, green leaves and yellow with red streaks } \\
\text { corm flesh }\end{array}$ \\
\hline
\end{tabular}

\section{Swamp Performance of Cultivars}

Aintablian (2011) reported the United States Geological Survey of what constitutes saline water such as low salinity (1,000-3,000 ppm), moderate salinity (3,000-10,000 ppm) and high salinity (10,000-35,000 ppm).
The 15 cultivar groups responded to low water salinity in the swamp at different magnitudes in terms of growth parameters such as monthly increment of corm diameters, survival, leaf damages and sucker formation (Tables 1,2, ,3 and 4). However, the responses were not statistically significantly in the swamp with an average of more than 1,000 ppm 
(1\%). Plant height, number of leaves and stalks were also non-significantly different.

Most of the cultivars collected grew slowly. However, few were fast growers (Table1). Typical symptom of salt injury is growth reduction expressed in slow corm diameter increase due to inhibition of cell expansion.

Table 2. Monthly corm diameter increase of 15 cultivar groups in a Chuuk swamp (2011-2014).

\begin{tabular}{|l|c|c|c|}
\hline Rating & $\begin{array}{c}\text { Monthly corm increase } \\
(\mathrm{cm} / \text { month) }\end{array}$ & $\begin{array}{c}\text { Groups } \\
\text { Percentage } \\
\text { distribution } \\
(\%)\end{array}$ \\
\hline Poor & $<1$ & $1,6,7,9,11,12,13,15$ & 53.4 \\
\hline Fair & $1.0-1.9$ & $2,4,5,8,10$ & 33.3 \\
\hline Good & $>2$ & 3,14 & 13.3 \\
\hline
\end{tabular}

Only two out of 15 cultivar groups had good survival rate of 80-100 percent due to daily exposure to high tide (mean of $0.8 \mathrm{~m}$ ) lasting for 6-8 hours (Table 2).
Majority of them demonstrated 60-79\% survival. This trend indicated varietal differences in growth vigor of the giant swamp taro.

Table 3. Percentage survival rates of 15 cultivar groups in a Chuuk swamp (2011-2014).

\begin{tabular}{|l|c|c|c|}
\hline Rating & Survival rates (\%) & Groups & $\begin{array}{c}\text { Percentage } \\
\text { distribution } \\
(\%)\end{array}$ \\
\hline Poor & & & 40.0 \\
\hline Fair & 660 & $1,4,5,6,9,12$ & 46.7 \\
\hline Good & $80-100$ & $2,3,7,8,10,14,15$ & 13.3 \\
\hline
\end{tabular}

All plants sustained leaf damages at various magnitudes (Table 3). However, sixty percent of these cultivars showed slight burning of leaf edges and tips. Accumulation of salt ions in plant tissues frequently causes toxicity manifested to plants by chlorosis and necrosis of leaf tissues (Torabi, 2014)

Table 4. Percentage leaf damages of 15 cultivar groups in a Chuuk swamp (2011-2013).

\begin{tabular}{|l|c|c|c|}
\hline Rating & Leaf damages & Groups & $\begin{array}{c}\text { Percentage } \\
\text { distribution (\%) }\end{array}$ \\
\hline Poor & $\begin{array}{c}\text { Entire population with damaged } \\
\text { leaves }\end{array}$ & 7 & 6.7 \\
\hline Fair & $\begin{array}{c}\text { Slight to full damages of several } \\
\text { plants }\end{array}$ & $5,8,9,10,13$ & 33.3 \\
\hline Good & Slight damages of some plants & $1,2,3,4,6,11,12,14,15$ & 60.0 \\
\hline
\end{tabular}

Approximately $80 \%$ of the population produced 1-2 suckers per plant, which was an optimum number for good productivity to reduce competition for space, light and nutrients (Table 4).

Table 5. Mean sucker number of 15 cultivar groups in a Chuuk swamp (2011-2014).

\begin{tabular}{|l|c|c|c|}
\hline Rating & Mean sucker number & Groups & $\begin{array}{c}\text { Percentage } \\
\text { distribution } \\
(\%)\end{array}$ \\
\hline Poor & $>3$ & 9 & 7.0 \\
\hline Fair & $2-2.9$ & 4,2 & 13.0 \\
\hline Good & $<1-1.9$ & $1,2,3,5,6,7,8,10,11,12,13,15$ & 80.0 \\
\hline
\end{tabular}




\section{Level Rise Mimicry Experiments}

\section{Time-series Soaking}

Fanan and Simiten lost their roots at different hours of soaking and magnitudes (Figure 1). Critical loss of their roots started between 6-8 hours of submergence in water salinity of more than $5 \%$. As soaking progressed, both of them had sustained root injuries resulting to root losses.

\section{Mean root numbers of two cultivars soaked at various hours}

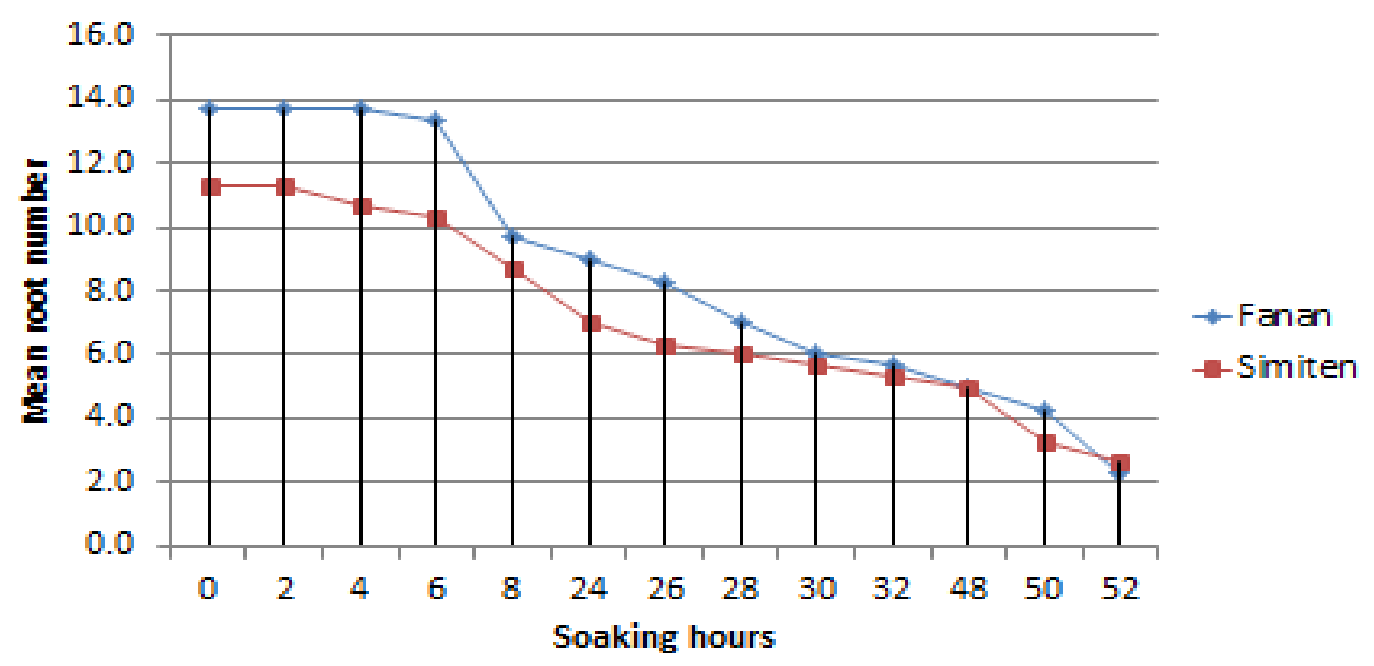

Figure 1. Mean root number losses of Fanan and Simiten at 0-52 hour soaking in seawater

Both Fanan and Simiten exhibited same trend of potassium absorption from the soak water that lost more than $50 \%$ of its potassium content at 2-hour soaking (Figure 2) Afterwards, the potassium contents of the soak water decreased slightly indicating that the root integrity of both cultivars was impaired due to root injuries. This phenomenon happened due to the survival instinct of the plants to absorb potassium under salt stress to exclude sodium from the plant cells (Wang et al). High cytosolic $\mathrm{K}+/ \mathrm{Na}+$ ratio is one key determinant to salt tolerance of plants (Maathuis and Amtmann 1999). 


\section{Potassium (K) contents of two cultivars' soak water at various soaking hours}

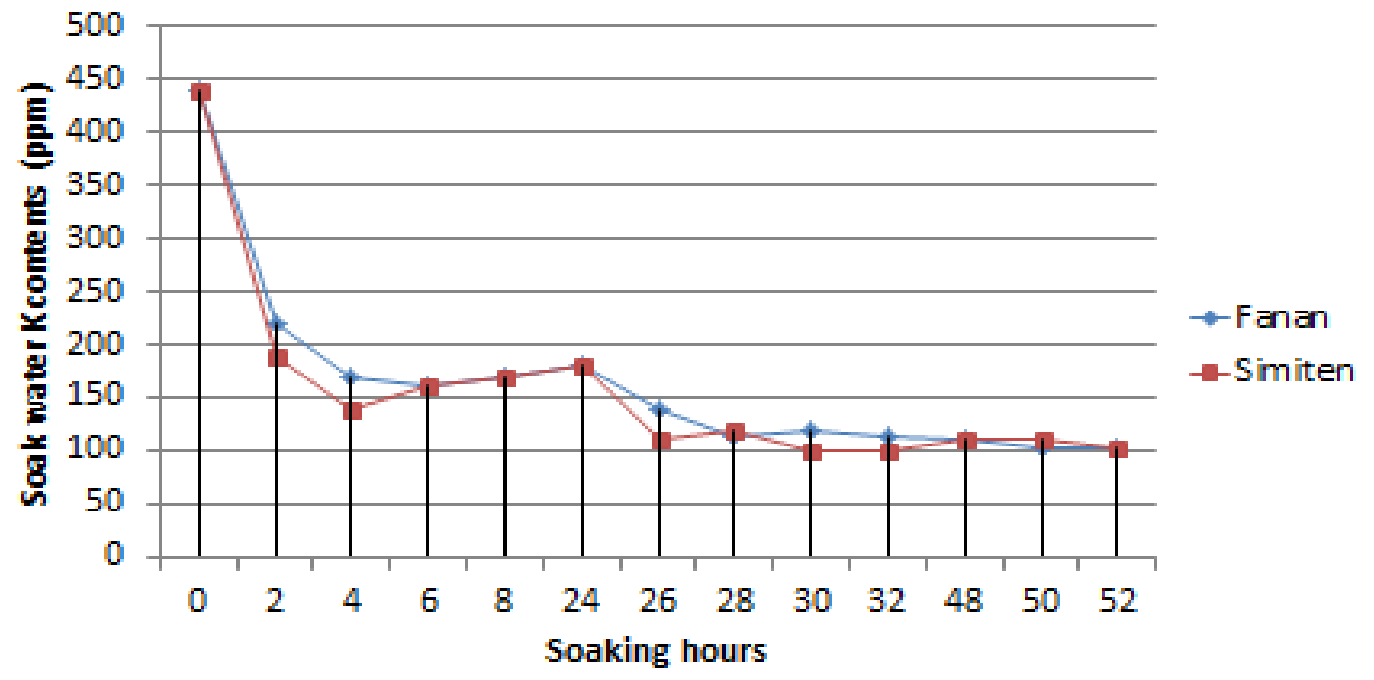

Figure 2. Potassium contents of soak water from 0-52 hours of soaking

Fanan and Simiten released phosphorus from injured roots slowly within 24 hours. At 26 hours, phosphorus leaching increased, peaked at 28 hours and levelled off at 30 hours up to 52 hours. Plants respond to salt stress by the production of Responsive Oxygen Species (ROS) such as superoxide, hydrogen radical and hydrogen peroxide ( Yadab et al 2011, Shabala and Cuin, 2008). Degradation of macromolecules in the cells such as membrane lipids, protein and nucleic acid results when ROS fail to be inactivated (Mittler, 2002). Such a process probably explained the leaking of phosphorus from the injured plants. Phosphorus performs as the structural element in nucleic acids and phospholipids. 


\section{Phosphorus ( $\mathrm{P}$ ) contents of two cultivars' soak water at various soaking hours}

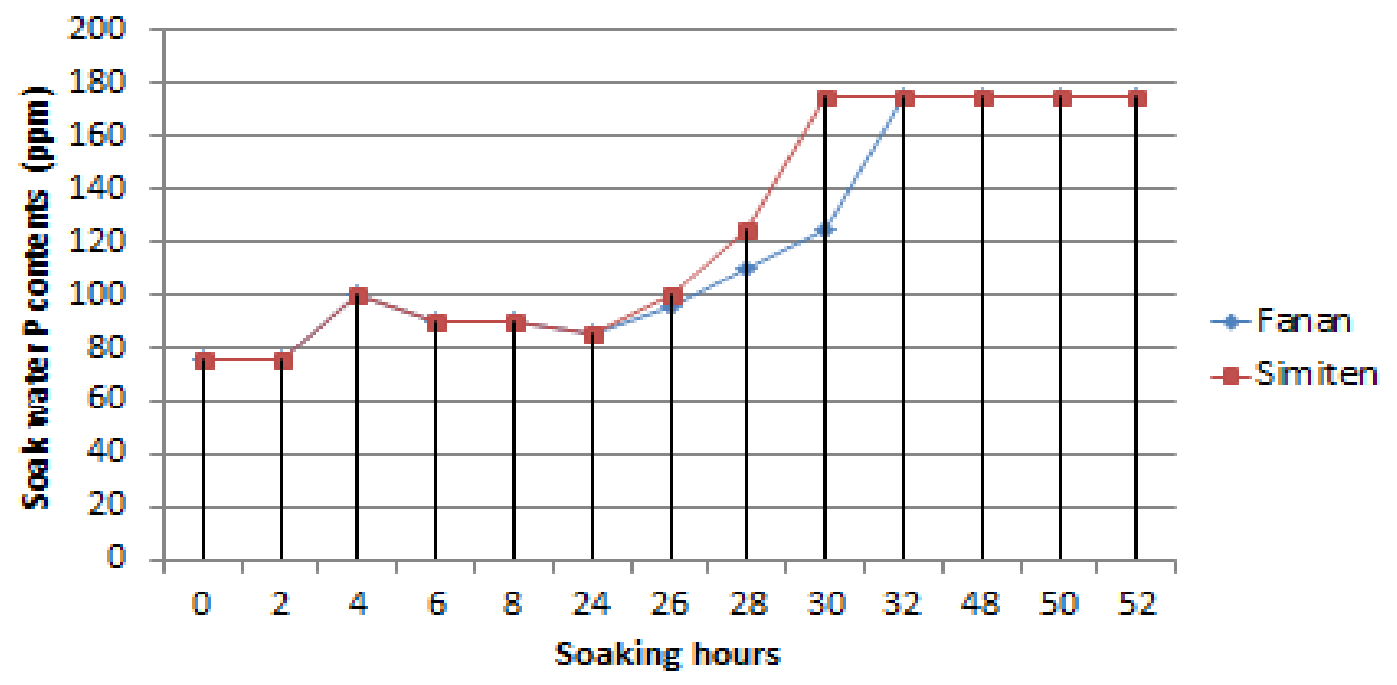

Figure 3. Phosphorus contents of soak water during 0-52 hours of soaking

\section{Seven-hour soaking}

Mean root number was significantly affected among the plant parts soaked for seven hours in seawater $(>5 \%)$. In the biomass, the stalks and leaves though scalded remained intact. However, the root system was heavily damaged
(Table 5). Under high salinity, plants suffer osmotic and ionic stress due to the salts accumulated at the outside of the roots and those accumulated at the inside of the plant cells (Horie et al 2012).

Table 5. Means of root length, root number, biomass and corm diameters of 15 cultivar groups before and after 7-hour soaking in undiluted sea water (2014)

\begin{tabular}{|l|c|c|}
\hline Parameters & Before soaking & After 7-hour soaking \\
\hline Mean root length $(\mathrm{cm})$ & 19.2 & $17.3^{\text {ns }}$ \\
\hline Mean root number & 65.9 & $56.1^{*}$ \\
\hline Biomass $(\mathrm{kg})$ & 0.8 & $0.7^{\text {ns }}$ \\
\hline Corm diameter $(\mathrm{cm})$ & 15.0 & $13.4^{\text {ns }}$ \\
\hline $\mathrm{t}_{(0.05)}$ & 2.14 & \\
\hline
\end{tabular}

Forty seven percent of the cultivar groups with $0-10$ root losses were considered good while those with more than 20 root losses were rated poor (Table 6). 
Table 6. Root number losses of 15 cultivar groups at 7-hour soaking (2014)

\begin{tabular}{|l|c|c|c|}
\hline Rating & Number of roots lost & Groups & $\begin{array}{c}\text { Percentage distribution } \\
(\%)\end{array}$ \\
\hline Poor & $>21$ & $1,2,7,14,15$ & 40.0 \\
\hline Fair & $11-20$ & 8,13 & 16.3 \\
\hline Good & $0-10$ & $3,4,5,6,9,10,11,12$ & 46.7 \\
\hline
\end{tabular}

\section{SUMMARY AND CONCLUSION}

This research dealt on collection and evaluation of local swamp taro cultivars from two states of the FSM for salt tolerance for more than two years.

The collected 43 cultivars bearing different names from different states and villages were grouped into 15 cultivar groups after morphological characterization.

The giant swamp taro seedlings showed variable adaptability in growing under a mild saline swamp . These seedlings demonstrated their inherent capabilities to withstand mild salt stress based on survival, leaf damages, sucker number per plant and monthly corm diameter increase for two years.

High salt stress using soaking in undiluted seawater (>5\%) to mimic effects of sea level rise in plant parts of giant swamp taro revealed the protective mechanism of the giant swap taro in a prolonged exposure to high water salinity. The two cultivars had different timing in accumulating potassium to exclude excessive salts entering their plant parts. The release of phosphorus differed in both cultivars suggesting the existing variation in disintegration of cell membranes in extreme water salinity stress.

The time series (0-52 hours) and the 7-hour soaking in sea water with at least $5 \%$ salinity level consistently indicated that root number losses could be a practical selection criterion for salt tolerance in giant swamp taro.

The different salinity responses of the local cultivars demonstrated the existence of variation in the FSM gene pool. Two cultivar groups (3 and 11) were potentially salt tolerant for the FSM based on the sea water soaking experiments.

Emerging issues regarding salt tolerance of giant swamp taro need further exploration.. These are: the tensile strength and structure of root systems of cultivars at different growth stages and salinity levels; nutrient translocation at different plant parts at various salinity concentration, plant ages and water salinity levels, corm yield, eating and storage qualities of cultivars at varying salinity concentration and upland adaptability trials.

\section{ACKNOWLEDGEMENTS}

The authors acknowledged the funding of the twoyear collaborative project called "Sustainable Taro Production under high Salinity in the Pacific" Accession No. 58-5320-0-264 under TropicalSubtropical Agricultural Research TSTAR/National Institute of Food and Agriculture (NIFA)/United States Department of Agriculture (USDA).

Special thanks were extended to our project collaborators: Dr. Daniel Aga (American Samoa Community College, ASCC), Dr. Tracie Matsumoto (USDA, Agricultural Research Service (ARS), United States Pacific Basin Agricultural Research Center (US PBARC), Emily Ilaoa (ASCC), Dr. William Sakai (University of Hawaii (UH) at Hilo) and Aufa Areta (ASCC).

Gratitude and appreciation were expressed to the following for continuing support: Dr. Singeru Singeo and Ric de Vera (COM-Land Grant), Vice President Jim Currie, Chuuk CRE Coordinator Mike Abbe, Yosko Kim and Kathryn Bisalen (COM-FSM CRE; Mereseni Seniloli (formerly at the Secretariat for Pacific Community); Innocenti Penno (deceased) and Sabrino Robert (Chuuk Department of Agriculture), Valentine Chipen (former CRE Agriculture Extension Agent); Wesney Nakayama (Chuuk Conservation Society); Jacinta Francis (Conservation Society of Pohnpei); Chuuk and Pohnpei taro farmers and Mesewin Sonis (swamp land owner) 


\section{REFERENCES}

Aintablian, A. 2011, Water-desalination-Desalination expands as technology becomes more affordable. Date of access: 20/07/2014.

www.geography. About com/od/water and ice/waterdesalination.htm

Brown, R . 2014, Can 52 island nations convince the world to keep them afloat? The Christian Science Monitor. Date of access: 14/10/2015

news.yahoo.com/52-island-nations-convince-worldkeep-them-afloat-134259549,html,

Hezel, F. 2009, High Water in the Low Atolls. Date of access: 03/06/2011.

http://micsem.org/pubs/counselor/highwater.htm.

Horie, F., Karahara, I. and Katsuhara, M., 2012.

Salinity tolerance mechanism in glycophytes: an overview with the central focus on rice plants. Date of access: 23/06/2016

thericejournal.springeropen,com/articles/10.1186/193 9-8433-5-11.

Maathuis, F. and Amtmann, A. 1999. K+ Nutrition and $\mathrm{Na}+$ toxicity: The basis of cellular $\mathrm{K}+/ \mathrm{Na}+$ Ratios. Annals of Botany 84: 123-133 (Issue 2). Date of access: 23/06/2016.

aob.oxfordjournals,org/content/84/2/123. Abstract? Ijkay+2b22cf77946 e382695 c88 d4036835a987619209f\&key1+stress tolerance.pdf.
Mittler, R. 2002. Oxidative stress antioxidant and stress tolerance. Trends Plant Sci 7: 405-410. Date of access: 23/06/2016

biol.unt.du/rmittler/Papers/oxidative-stress antioxidant

Ragus, L. and Sonis, W. 2015, Giant Swamp Taro Guide.COM-FSM Chuuk/Cooperative Research and Extension, Weno, Chuuk FSM.

Shabala,S. and Cuin, Ta,. 2008. Potassium transport and plant salt tolerance. Physiol. Plantarum 133:651669.

Torabi, M. 2014, Physiological and biochemical responses of plants to salt stress. The $1 \mathrm{st}$ International Conference on New Ideas in Agriculture. Islamic Azad University, Khorasgan Brana, 26-27 January 2014. Date of access: 26/06/2016.

khuisfp.ac.ir/dorsapax/userfiles/file/pazhohesh/ideha9 2/033.pdf

Wang, M., Zheng,Q., Shen, S. and GUO, S.. 2013, The critical role of potassium in plant stress response. Date of access: 22/06/2016

www.ncbi,nlm.nih.gov.

Yadao,S, Irfan, M., Ahmad, A., and. Hayat, H. 2011. Causes of salinity and plant manifestation to salt stress: a review. J. Environ. Biol. 32: 667-685. Date of access: 23/06/2016.

citeseerx.ist.psu.edu/viewdoc/download? doi=10.1.1.461.1752 \& rep=rep1. 